\title{
Petrakovo rjavenje listja gorskega javora, Petrakia echinata
}

\section{Tine HAUPTMAN}

Gliva Petrakia echinata je sicer že dolgo poznana kot povzročiteljica bolezni listov gorskega javora, nekoliko večje zanimanje pa je vzbudila šele leta 2003, ko so se v Avstriji začele pojavljati nekoliko močnejše okužbe. V zadnjih letih je vse bolj pogosta tudi v Sloveniji. Do sedaj smo jo $z$ mikroskopiranjem določili le v urbanem okolju (Arboretum Volčji Potok, Ljubljana), ker pa simptome bolezni opažamo tudi v gozdnem prostoru (pred kratkim so nas gozdarji obvestili o močnem pojavu bolezni v okolici Polhovega Gradca) vas prosimo, da nas o morebitnem pojavu okužb in prezgodnjem odpadanju listja obvestite.

Značilni simptomi bolezni, ki jo povzroča omenjena gliva, so do $6 \mathrm{~cm}$ velike, sivo rjave do temno rjave pege na listih gorskega javorja (Acer pseudoplatanus) (slika 1 in 2). Pege so največkrat okrogle do elipsaste oblike, na njih pa so koncentrični kolobarji, ki kažejo, kako se gliva skokoma širi v listu v zanjo ustreznih razmerah za rast. Ob močni okužbi se lahko več peg združi in na koncu obsega celotno listno površino. Gliva na pegah oblikuje nespolna trosišča - sporodohije (slika 3), ki so sprva opazni kot belkaste pike, kasneje pa postanejo rjavi in nato črni. Sporodohiji vsebujejo konidije (slika 4), ki so običajno rjavi, kroglasti do elipsasti, septirani in z dvema do šestimi izrastki, ki so ravni in brezbarvni. Ob močni okužbi gliva povzroči predčasno odpadanje listja. Z zatiranjem glive nimamo izkušenj, domnevno je učinkovita jesenska odstranitev odpadlega listja, ki naj bi onemogočila ponovno okužbo listja naslednjo pomlad. Sicer pa kakšni posebni varstveni ukrepi niso potrebni.

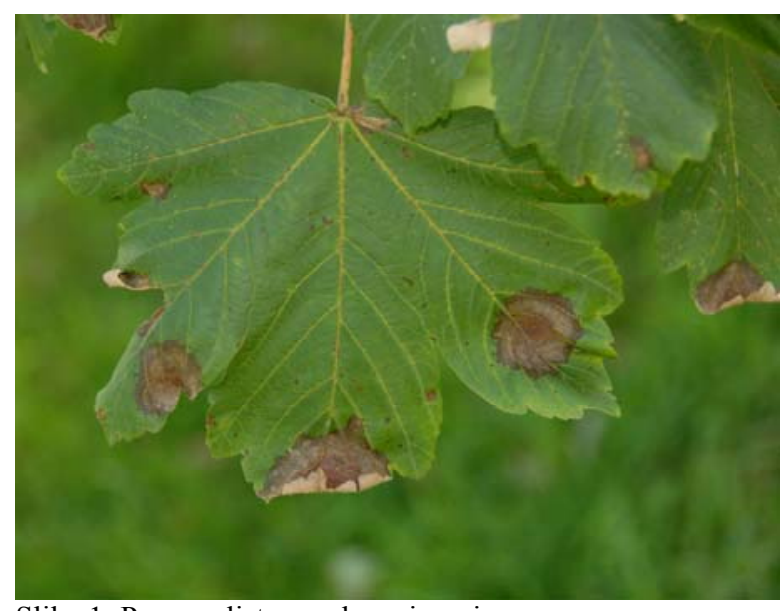

Slika 1: Pege na listu gorskega javorja

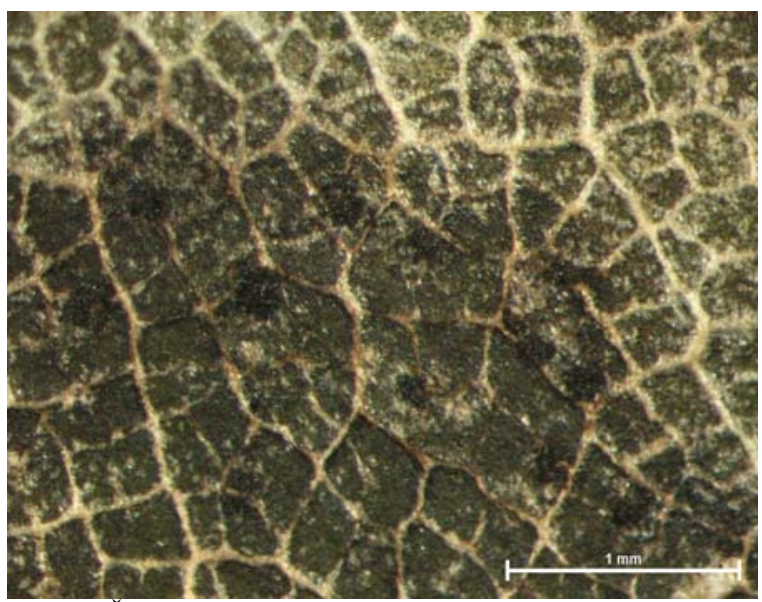

Slika 3: Črna trosišča - sporodohiji

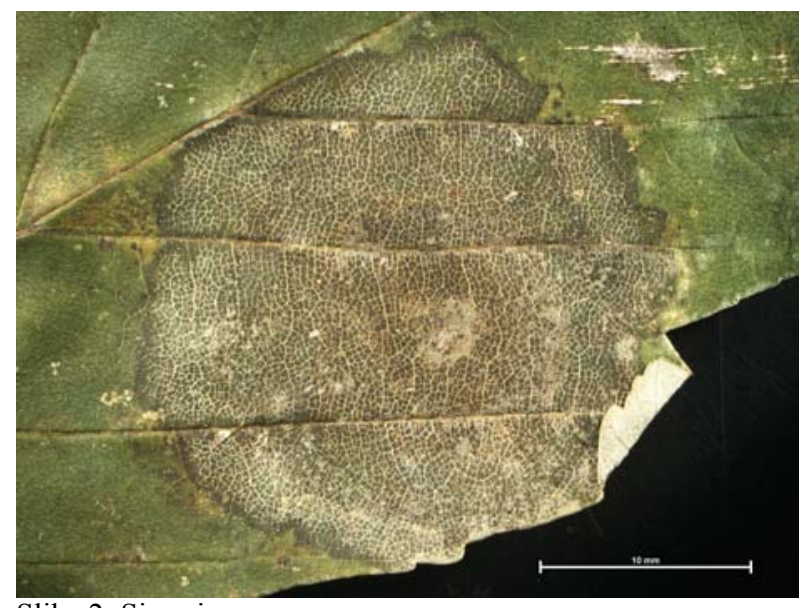

Slika 2: Sivo rjava pega

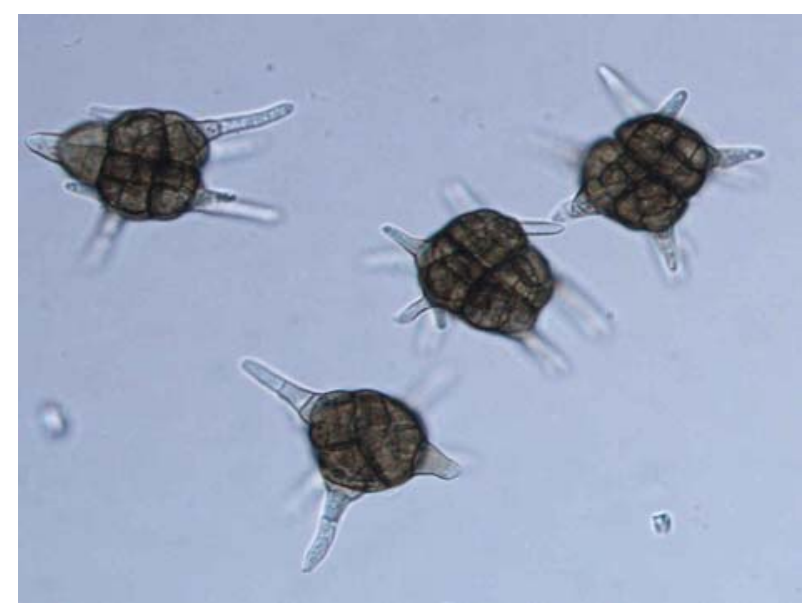

Slika 4: Konidiji glive Petrakia echinata 